Part One

The Northern Impact 



\title{
The Russian Revolution and Civil War in the North: Contemporary Approaches and Understanding
}

\author{
Vladislav Goldin \\ (Northern [Arctic] Federal University, Arkhangelsk)
}

7 he aim of this article is to analyze the particulars of the development of the 1 Russian Revolution and Civil War in the North. The term "North" (that is, the European north of Russia) implies the territory of three provinces within the administrative borders of the Russian Empire in 1917—the Arkhangelsk, Vologda, and Olonets provinces. This vast and varied territory, large enough to contain several European countries, had a population of approximately 2.7 million by 1917. Today, it includes the Komi and Karelian republics, as well as the Arkhangelsk, Murmansk, and Vologda provinces.

There is a large historiography devoted to the Russian Revolution and Civil War in the North. Since the 1920s, more than a hundred books on this subject have been published, dozens of dissertations defended, and several thousand articles issued in the USSR/Russia and abroad.

At the beginning of the twentieth century, the Russian North was a huge and sparsely populated region with immense natural resources. It was a border region with close commercial and cultural contact with foreign countries and their populations. Russian northerners had their own specific way of life and an established, unique, and productive culture. The main features of the northern mentality were independence, freethinking, and a tradition of mutual assistance. There was a democratic outlook, a sense of fearlessness and tranquility, and no inclination to apply brute force for eliminating contradictions and conflicts.

In order to characterize the social and economic situation in the North before the Revolution of 1917, it is important to stress that notwithstanding rapid industrial development elsewhere (industrial production in 1917 was 
twice that of 1900), the North was mainly rural. More than 90 percent of the population (although less than 90 percent in the province of Arkhangelsk) lived in the countryside. Agriculture was one of many sources of livelihood for the northern peasantry. Hunting and fishing, seasonal work, numerous handicrafts producing goods for sale, lumbering and sawing of timber, peddling goods, and so forth, could be seen in different combinations from one area to another. Most northern peasants lived in social communities (obshchina). Northern state peasants had no experience of the evils of landlordism and were less susceptible to radicalism before and after 1917.

There were about 35,000 industrial workers in the large factories of the North, including 24,000 working at sawmills before 1914. Approximately 25,000 worked on northern railroads, and after the Murman railway was built this group grew rapidly during the First World War. Port workers, especially those evacuated from Latvia throughout the war, played an important role in the revolutionary events in Arkhangelsk and Murmansk. The total number of non-industrial workers in the three northern provinces was more than $380,000 .^{1}$

The leaders of the local elite, entrepreneurs, and the intelligentsia believed that government policy in the North was too centralized, and that it was unable to recognize the peculiar needs of the northern economy and society. They demanded a modernization of the North and more control over local affairs through institutions of local self-government. Their relations with the government were uneasy in many respects. Nevertheless, the political situation in the North, before and during the Great War according to police accounts, was stable. The influence of the revolutionary parties was limited and did not seriously disturb the local authorities and police either before or during the war.

The news about the February Revolution of 1917 and the overthrow of the tsar reached the North via telegraph and was warmly welcomed by the different social groups of the population. There were many meetings, demonstrations, and solidarity marches. The Festival of the Revolution was celebrated in Arkhangelsk on March 10 with the participation of 20,000 to 40,000 people from different social strata. The first, short period of the revolution was characterized in the North, as in the whole country, by joy, dreams, and hopes, with mass public activities and the establishment of many new institutions and organizations.

1 Mikhail I. Shumilov, Oktiabr'skaia revoliutsiia na Severe Rossii (Petrozavodsk: Kareliia, 1973), 26-27. 
In March 1917, Soviets of workers' and soldiers' deputies were organized in the towns of the region and later Soviets of peasants' deputies were established in the countryside. The coalition of SRs (Socialist Revolutionaries) and Mensheviks dominated most of the northern Soviets almost entirely in 1917. In the first days and weeks of the revolution, ideas of class compromise were popular, along with cooperation among different social and political groups and organizations. As a result, in March 1917 Arkhangelsk, Vologda, and certain other towns, were each given their own committee of public security. These committees included representatives of self-government, public and business organizations, and Soviets that had recently been formed. In June 1917 the Provisional Government finally established a zemstvo ${ }^{2}$ for the first time in Arkhangelsk province.

Soldiers and sailors were at the heart of political life in the Northern Region, as well as in Russia as a whole. There were 43,000 of them in the North, and they founded their own organizations in 1917: the Central Committee of the Arctic Flotilla; the Central Committee of the Army; and the Central Committee of Soldiers' Delegates in Arkhangelsk. These organizations (especially the Central Committee of the Arctic Flotilla) were radical, with a strong Bolshevik element. They demanded that Soviets take control of local affairs and lead the revolution to the next stage. Alongside these developments, there was also growth in trade unions, workers' factory committees, and the cooperative movement in the North.

Local political parties were rather small in the North. There were about eighteen hundred SRs in Vologda province at the end of summer 1917 and a few hundred of them in Arkhangelsk and Olonets provinces. There were approximately nine hundred Kadets (Constitutional Democrats) in Vologda province and even fewer in Arkhangelsk and Olonets provinces. ${ }^{3}$ There were a few hundred Bolsheviks in the northern provinces.

Possibilities for regional policy and politics expanded greatly after the fall of the tsar. Different political and social organizations began to

2 Zemstvo was an institution of local self-government created on an elected basis and instituted during the reforms of 1860s and during the few next decades in Imperial Russia. However, these bodies were not instituted in all provinces of the state. In the North, they were instituted in the Vologda and Olonets provinces and not in the Arkhangelsk province because the composition of its population was considered too democratic.

3 Shumilov, Oktiabr'skaia revoliutsiia, 78, 107; Andrei N. Egorov, "Kadetskie organizatsii Vologodskoi gubernii v 1917-1918 gg.," in Evropeiskii Sever: istoriia i sovremennost' (Petrozavodsk: KNTs AN SSSR 1990), 43. 
realize their own aspirations in the North in 1917, as well as in Russia at large, and to work out their own programs. All this had both positive and negative consequences. No effective system of governance was established by the Provisional Government (after the destruction of the old tsarist one) - neither at state, regional, nor local level. All over Russia, including the North, many organs and organizations tried to put pressure on governance or even govern. The final result was poor.

After the short first stage of revolution - with its joy and celebration-a destructive phase began. In Russia, and in the North especially, there were numerous growing crises. There were problems with the supply of food and industrial goods; the standard of living was falling; and there was dissatisfaction with the authorities. However, no bloody conflicts arose in the northern provinces in 1917, and political struggle was carried out by peaceful means.

The news about the Bolsheviks' accession to power in Petrograd was followed by discussions in the Northern regional and local institutions, zemstvo municipal self-governing bodies, and Soviets in the northern provinces. Most of them did not support the new central power. Only a few Soviets in small towns such as Murmansk, Soroka, Kandalaksha, Sukhona, and Sokol recognized the Bolshevik government immediately. An acute political contest for power became a reality in most northern towns.

Most of the population lived in small and widely dispersed settlements that were isolated from each other. People suffered from a lack of information about political processes and took a position of "wait and see." Among the northern, moderate socialists, the ideas of "democratic power, including all the shades of political parties, united in the Soviets" and a "homogeneous" government were popular. But these proposals were rejected by the Bolsheviks. The relations between the various Russian socialist groups became ever more irreconcilable.

The elections to the Constituent Assembly in November 1917 were a clear indicator of the political preferences of the northerners. The SRs won in the countryside, but in the towns the majority of the population generally voted for the Bolsheviks (Arkhangelsk; Murmansk), or Kadets (Vologda; Velikii Ustiug). On the whole, 73 percent of northerners voted for the SRs, 15 percent for the Bolsheviks, 7.3 percent for the Kadets, and 0.9 percent for the Mensheviks. ${ }^{4}$ In total, eight SRs, one independent (who went over to the Bolsheviks), and one Bolshevik were elected as deputies of the Constituent Assembly.

4 Leonid M. Spirin, Klassy i partii v grazhdanskoi voine v Rossii (Moscow: Mysl', 1968), 416; Iurii M. Rappoport, Osushchestvlenie ekonomicheskoi politiki Kommunisticheskoi partii v usloviiakh Evropeiskogo Severa, 1917-1925 (Leningrad: LGU, 1964), 12. 
Since the end of 1917, the influence of the Soviets and the position the Bolsheviks had in them had been increasing. By the spring of 1918 the Bolsheviks, in alliance with the left SRs, were already in control of all provincial and most municipal and district Soviets in the North. Their position was not firm, however. Most of the population, primarily the peasants, again took a neutral "wait and see" position. In the end, the status of the new authorities depended on their ability to find a way out of the deep crisis into which the country and the Northern Region had plunged.

The origins and beginning of international intervention and the civil war in the North were connected with the small port town of Murmansk and its neighboring territory, Murman. These events (of 1917 to the first half of 1918) were not only of regional, but also of national and international importance, and became a significant milestone in the history of intervention and the Russian Civil War.

For a long time, the Murman coast had been a sparsely settled region with a population of a few thousand people. This changed during the Great War. The recently constructed town of Murmansk became the only ice-free port in European Russia that was suitable for landing Allied war supplies. The railway that connected the port with the capital was completed at the end of 1916. Murmansk also became a major Russian naval base in the High North and served as a base for the Allied (mostly British) navy, which had been stationed in the waters of the Barents and White Seas since 1915. The navy's task was to protect the vital northern sea lanes against floating mines and attacks by German submarines. British Rear Admiral Thomas W. Kemp was commander of the naval squadron.

The strategic importance of Murman explains why the Entente coalition countries, primarily Britain, wished to strengthen their hand in the area. A secret Anglo-French agreement on the division of spheres of influence in the south of Russia was signed in Paris on 23 December 1917. It was also agreed that the Russian North would be a British sphere of influence. British Secretary of State for Foreign Affairs, Arthur F. Balfour, wrote in January to the consul general of the British Embassy in Petrograd, Francis O. Lindley, that the British government considered their continued presence in the northern area to be desirable and "had no intention of withdrawing the naval forces at Murmansk." Frederick C. Poole, the British general and chief of the Russia Supply Committee in Petrograd, wrote to London in January 1918: "Of all the schemes I have heard, the one I like best is to boost up the Northern Federation-with Arkhangelsk as center. There we could easily 
consolidate the Government-one Man of War in the harbor would do that. We could reap a rich harvest in timber and railway concessions and control the two Northern Ports."5

At the end of 1917, the population of Murmansk numbered about 13,000 and consisted almost entirely of newcomers: railroad and construction workers and their families, as well as soldiers and sailors. This was a transient population that did not intend to stay in the area. The Murmansk Soviet was predominantly unaffiliated to a party, but was the first in the North to acknowledge the Bolshevik government in Petrograd (on 26 October 1917). The main military commander of the Murmansk Fortified Region (Glavnomur), Rear Admiral Kazimir F. Ketlinskii, driven by the need to maintain both defense and order, supported this decision. The Bolshevik influence was considerable in the main public organizations: Murmansk Sovzheldor (the local committee of the Union of Murman Railwaymen) and Centromur (the Central Committee of the Murmansk Flotilla).

During the first half of 1918, the general situation in Murman transformed profoundly for the following reasons, among others: the demobilization of the soldiers and sailors; the departure of the construction workers; the murder of Ketlinskii; a change of the structure, status, and staff of the Murmansk Soviet; a growing dependence on Allied provisions; a political and military crisis involving primarily Britain and Germany; and territorial claims of the White Finns and their raids on the region.

The Entente representatives did their best to strengthen both their own significance and the ambitions of separatists in the region. Naval officer Georgy M. Veselago, executive secretary of both the People's Collegium and the Murmansk Soviet, and his anti-Bolshevik companions in arms (former general Nikolai I. Zvegintsev, chief of the local military forces, Vladimir M. Bramson, head of the Department of Civil Governance, etc.), favored the gradual selfisolation of the region from the Bolshevik government. They wished to create in Murman a separate regional administration (independent of Arkhangelsk and Moscow) under Entente protection.

Allied intervention in North Russia, initially in Murman, began in a unique international situation. The interests of the warring coalitions-the Entente countries, and the Central Powers, represented primarily by Great Britain and Germany-were pushed relentlessly there. Furthermore, it is necessary

5 Andrew Rothshtein, When Britain Invaded Soviet Russia: The Consul who Rebelled (London: Journeyman Press, 1979), 60-61. 
to take into consideration the Finnish Civil War (January-May 1918), where the White Finns were supported by Germany and the Red Finns by Bolshevik Russia. The objectives of the White Finns and Germany concerning North Russia (Murman and Karelia, especially) were obvious.

Several documents and events during the first week of March 1918 illustrate the different and contradictory interests, trends, and tendencies that guided the situation in Murman and the Russian North as a whole:

1. The treaty of March 1 between the Bolshevik government and the Finnish Socialist Workers government;

2. The so-called "Oral Agreement" of March 2 between the Murmansk Soviet and military representatives of the Entente. (The necessity of accepting Allied assistance to defend Murman against the threat of the White Finnish invasion was sanctioned by the people's commissar Lev D. Trotskii in his telegram of March 1);

3. The Brest-Litovsk Treaty of March 3 between Bolshevik Russia and the Central Powers;

4. The landing of the German forces on the Aland Islands on March 5 -the prologue to the major German intervention in Finland a month later;

5. The landing of the first detachment of British Royal Marines in Murmansk on March 6;

6. The agreement of March 7 on cooperation between Germany and the White Finns.

It was the beginning of the "Great Game" in Murman, with participation by Soviet Russia, regional and local authorities, the Entente countries, Germany, socialist Finland, and White Finland. All the participants tried to realize their own goals. The Allies hoped to organize intervention in Russia "by invitation" or "with consent" of the Bolshevik government and to thereby reestablish the Eastern Front. Germany wanted the Russian government to adhere to the Brest-Litovsk Treaty, and had intentions to occupy or control the Murmansk area, the northern Russian ports, and the Murmansk railway. It also wanted to push the Entente naval ships and military forces out of the Russian North. The Red Finns hoped to include western Murman and eastern (Russian) Karelia in the Finnish Socialist People's Republic as a result of an agreement with the Bolshevik government. The White Finns dreamed about a Great Finland ranging from the Arctic up to the Baltic Sea, and began military raids in spring 1918, to seize Murman and eastern Karelia. Hoping to bide their 
time until the commencement of world revolution - which they believed was imminent - the Bolshevik leaders dealt evenhandedly with both the German coalition and the Entente, as well as tried to prevent them from fighting on Russian soil.

In spring and June 1918, the Allies, headed by Britain, strengthened their sway in Murman step-by-step. They sent warships and landing troops, and supported local anti-Bolshevik elements and their separatist ambitions. The Allies and their Russian associates tried to justify their increased military presence in Murman as a necessary response to the White Finnish and German threat to the region-especially after the victory of the White Finns in the civil war in Finland, which had been predetermined by German intervention.

The Entente forces, together with Soviet military detachments, engaged in fighting with the White Finns, who had invaded the border territories of Murman in spring and early June 1918, thus expanding their power and influence in the Russian North. At the beginning of June 1918, the Supreme War Council decided on an Allied military intervention in North Russia, portraying it as an anti-German move. General Poole, who was an ardent advocate of the Allied military intervention in northern Russia, actively participated in its planning and preparation. He arrived in Murmansk on May 24 as head of the British mission, and was appointed commander in chief of the Allied forces in Russia by the Supreme War Council at the beginning of June.

The Bolshevik government saw the growing danger of the Entente's anti-Bolshevik and anti-Russian character, but had no forces to prevent it. The government tried instead to use political and diplomatic means to protest against Allied activity in Murman and insisted, unsuccessfully, that the Murmansk Soviet do the same. On June 30, 1918, however, the Murmansk regional Soviet refused to execute these orders from Moscow and demanded withdrawal of the Entente troops. This meant a rupture with the Bolshevik government. The chairman of the Murmansk Soviet, Aleksei M. Uirev, was declared "an enemy of the people and an outlaw." ${ }^{6}$ On July 6, the so-called "Temporary Agreement" for cooperation was signed between the presidium of the Murmansk regional Soviet and the representatives of Great Britain, France, and the US. In reality, an occupation regime was established in Murman, and all spheres of life were controlled by the interventionists.

The Murman events of the summer of 1918 marked the beginning of the Russian Civil War in the North. The Entente intervention, initially proclaimed

6 Izvestiia VTsIK [News of the All-Russia Central Executive Committee], July 2, 1918. 
as anti-German, became in fact anti-Bolshevik and an undeclared war against Bolshevik Russia. The plans for moving most of the Czechoslovak Legion to the North failed, however, as a result of its anti-Bolshevik mutiny at the end of May. It meant the collapse of the initial Allied plans. A lack of sufficient military forces for the Russian North was a big challenge for the Allied countries and their military command. ${ }^{7}$

While the genesis of the civil war in the Russian North was connected in large part with the Entente intervention in Murman, it had numerous other causes: the deterioration of the socioeconomic and political situation both in the country at large and in the North; some extraordinary measures implemented by the Bolshevik authorities; and the persecution of the opposition and limitation of its activities. Conflict was also exacerbated by the use of illegal political and military methods by the Bolsheviks' rivals.

The Russian anti-Bolshevik organizations prepared a coup d'état in Arkhangelsk in collaboration with the Entente military representatives and diplomats. The coup in Arkhangelsk on August 2, 1918 took place simultaneously with the arrival of the Allied fleet and military intervention. These events, and the beginning of a full-scale military intervention, signaled a new stage in the civil war in Russia. Without the Allied interposition, the anti-Bolshevik struggle in the North would hardly have taken the form of civil war.

On August 2, the Supreme Administration of the Northern Region was formed in Arkhangelsk, headed by Nikolai V. Chaikovskii, a veteran of the Russian revolutionary movement, and one of the leaders of the Popular Socialist Party and the Union for the Regeneration of Russia. The Supreme Administration consisted mostly of SRs, and its first ten decrees began with the phrase, "For the sake of the Motherland and the achievements of the

7 The Czechoslovak Legion, originally an all-volunteer battalion, consisted of ethnic Czechs and Slovaks residing in the Russian Empire. In the summer of 1917, it was allowed to also include Czechoslovak prisoners of war. From 1917, the Czechoslovak Legion took part in the fighting in Ukraine, together with the Russian Army. On 25 March 1918, an agreement was signed between the Bolshevik authorities and representatives of the Czechoslovak National Council about the evacuation of the Czechoslovak Legion through Vladivostok to France. However, on May 2 the Supreme War Council of the Entente decided to use the Czechoslovak detachments as a nucleus of Entente forces in the intervention in the Russian North. This plan ran aground due to the anti-Bolshevik uprising of the Czechoslovak Legion, which was strung out along the Trans-Siberian Railway from Penza to Vladivostok at the end of May 1918. The Czechoslovak Legion became the main force of the Allied intervention in Siberia and the Far East, and contributed to the full-scale Civil War in Russia. 
revolution." ${ }^{8}$ Chaikovskii wrote in a letter from Arkhangelsk to Paris that "the program of the Supreme Administration aimed at restoring the democratic order of $1917 . " 9$

The real power, however, was in the hands of General Poole. He controlled the main spheres of life in the city and region, and acted without reference to, or respect for, the Supreme Administration. In short, he mistrusted the socialist government and supported right-wing organizations. Chaikovskii tried to appeal to the Allied diplomats who arrived in Arkhangelsk on August 9, but without definite results.

On the night of September 5 and 6, 1918, the group of officers headed by the commander of Russian military forces of the Northern Region, Captain Georgii E. Chaplin, arrested the members of the Supreme Administration and sent them into exile at the Solovetskii monastery located by the White Sea. This coup was organized by right-wing circles. After mass protests and intercession by Allied diplomats, the ministers were released and returned to Arkhangelsk. But the prestige of the Supreme Administration was severely undermined after the Chaplin putsch, and this event was highly important for the antiBolshevik movement and the subsequent course of events in the civil war in the Russian North. This experience demonstrated the sharp conflicts within the anti-Bolshevik movement, and the inability of its different factions to work together. The moderate socialists, who alone enjoyed wide popular support, were condemned by right-wing groups and the Allied military command for having carried out the policies of discredited former prime minister Kerenskii (kerenshchina). On the other hand, the anti-Bolshevik socialists mistrusted the ex-tsarist officers, who alone could organize a real military force for the struggle against the new regime. The Supreme Administration did not receive the support of the Allied military administration.

At the beginning of October 1918, Chaikovskii formed the Provisional Government of the Northern Region to replace the Supreme Administration, and was the only socialist in the new government. The term "Provisional" in the title of the government instead of "Supreme" was in recognition of the limited powers of the Russian authorities. The government asked its opponents "to give up local and class interests" and "to suspend the parties' difference of opinions" for the sake of "salvation of the Motherland," and to work jointly

8 Vestnik Verkhovnogo Upravleniia Severnoi Oblasti [Herald of the Supreme Administration of the Northern Region], August 10, 1918

9 State Archive of the Russian Federation (GARF). F. 5805, Op. 1, D. 132, L. 5. 
with the Allies. ${ }^{10}$ But it was nearly impossible to carry out this political course during the civil war. The majority of the population was indifferent to the government's promises and policies, and more interested in ending than in continuing the war.

The military situation in the North was very complicated. Initial plans for military intervention failed. They could reach neither Moscow nor Vologda on the Railroad Front, and seized only Obozerskaia station, located seventy miles to the south of Arkhangelsk. The attempt to reach Kotlas on the North Dvina Front also failed. The organization of the local armed forces had a poor start. A volunteer enrollment into the so-called Russian People's Army produced only 1,000 volunteers in August, and only 250 of them were sent to the front. ${ }^{11}$ An attempt at mass conscription failed. The local population had no wish to fight. At the same time, the Bolshevik resistance to the Allied intervention was growing. In September 1918, the Sixth Army was formed-under the command of former colonel Vladimir M. Gittis and former general Alexander A. Samoilo- to confront the interventionists.

The Allied intervention was anti-Bolshevik in character. It was not possible to describe it as a defense of the local population against the Germans, as there were none in the North. The situation worsened after the end of the First World War. Following the Armistice, it was not possible for the Allies to justify their activity using political, military, and strategic considerations connected with the Great War. Their anti-Bolshevik political and ideological motives were obvious, as were their geopolitical and economic intentions: control over the strategically important Russian border region (its ports, communications, and local economies); the acquisition of goods and raw materials (often without any consent from the local Russian authorities); and gaining concessions.

There were 23,516 foreign officers and soldiers, and only 7,156 (mostly mobilized Russians), in the armed forces of the Northern Region at the end of $1918 .^{12}$ All of them were under the British commander in chief, General William E. Ironside, who replaced General Poole in this position in October 1918. The number of Bolshevik forces ranged from 15,000 to 18,000 in the winter of 1918-1919.

Despite the official decision on the withdrawal of the Allied forces, the British war minister, Winston Churchill, did his best to convert the

10 Vestnik Verkhovnogo Upravleniia Severnoi Oblasti, October 9, 1918.

11 GARF. F. 16, Op. 1, D. L, 52. 54.

12 Army. The Evacuation of North Russia. 1919 (London H. M. Stationary Office, 1920), 19-20. 
evacuation into a full-scale offensive operation in the North, as soon as weather permitted. He dispatched fresh British reinforcements-two brigades of the Russian Relief Force-to Arkhangelsk in May-June 1919. Churchill planned to attack in the direction of Kotlas and thus join with Admiral Kolchak's White forces. ${ }^{13}$ But mutinies in the White Army of the Northern Region led to the decision to evacuate from the Russian North in the summer of 1919. The Allied command held that the continuation of the war without their support was senseless, and suggested the evacuation of the White forces. However, the commander in chief of the Northern Front, General Evgenii K. Miller, rejected this advice. He bet on White victories on the other main fronts of the Russian Civil War.

After the evacuation of the Entente troops, the leadership of the antiBolshevik Northern Region tried to look for new allies. All attempts, however, were unsuccessful: The Finns, who had dreamed of a Great Finland at the expense of Russia's northwestern territories, occupied the Pechenga area which had been controlled by the White Russians; and Karelian separatists seized some areas near the border with Finland (and with the help of the Finns) and tried to establish independent republics with their own governments.

The economic situation in the Northern Region worsened rapidly from late 1919 to early 1920. The government had always been dependent on foreign support. It needed foodstuffs and coal, for example, but suffered from a shortage of foreign currency and could not pay for supplies from abroad. The government tried to force the local population, primarily the business community, to increase its contribution to the war effort through volunteer actions. It also imposed special measures, such as strict regulations and a demand for exporters to surrender all foreign currency in exchange for Russian currency. All these measures failed to seriously improve the situation, and instead led to dissatisfaction among businessmen in both the North and abroad. The result was that the government lost support as its social base weakened. At the same time, the lower classes demanded improvements to their social and economic circumstances, and an end to the Civil War.

In February 1920, the White Northern Front collapsed because of army mutinies. The leadership and command of the Northern Region and Northern

13 Alexander Vasilevich Kolchak (1874-1920), a polar explorer and commander of the Imperial Russian Navy. During the Russian Civil War, he was proclaimed the Supreme Ruler and Commander in Chief of All Russian Land and Sea Forces. In other words, he was the leader of anti-Bolshevik Russia. His residence and his government were based in Omsk. In January 1920, he was arrested and later executed by the Bolsheviks. 
Front, as well as some groups of soldiers and civilians, managed to escape to Norway or Finland. This was the end of the Northern Front and civil war in northern Russia.

The civil war in the North, then-like the Russian Civil War as a wholewas a series, or complex, of conflicts:

1. between the Entente forces and the Bolsheviks, 1918-1919;

2. between Red Army and White Army detachments, 1918-1920;

3. between the Finnish "volunteers," who invaded Murman and Karelia, and the Bolshevik armed detachments supported by Entente sections, March-June 1918;

4. between the Reds and the Finns, 1918-1919;

5. between the Entente forces, together with the Finnish Legion and Karelian regiment (both of which were organized by the Allies), against the Finnish volunteers and the Karelian separatists, 1918-1919;

6. between the Karelian separatists supported by the White Finns and the Russian Whites, 1918-1920;

7. between the Karelian separatists and the supporters of Bolshevik power, 1918-1920;

8. mutinies, rebellions, and underground movements behind the frontlines of the Whites and Reds;

9. the activities of the White and Red partisan detachments.

Although the leaders of the Entente countries rejected responsibility for the civil war in North Russia, the Allies laid the groundwork for anti-Bolsheviks taking power in Murmansk and Arkhangelsk, and initiated the main fighting against the new regime's forces. The withdrawal of Allied forces led to the failure of the White cause in the North.

Disunity in the anti-Bolshevik movement was one of the main reasons for its defeat in the Russian Civil War. There were a number of conflicts within the opposition camp in northern Russia: between the Allied countries as participants of the intervention; between the military command and diplomatic corps of the Entente countries in the North; between the Allied countries, the Northern Region, and the White Finns; between the Allied military command and the administration of the Northern Region; and between different anti-Bolshevik political groups in the North. The White authorities could not solve the main questions that were put on the agenda-those concerning workers, peasantry, agriculture, and relations between the local and the national. They were fully 
16 Part One - The Northern Impact

dependent on support from abroad. The Bolsheviks skillfully capitalized on these failings, and carried out an effective propaganda offensive that accused their opponents of unpatriotic, anti-Russian, feelings and actions.

\section{Bibliography}

Shumilov, Mikhail I. Oktiabr'skaia revoliutsiia na Severe Rossii. Petrozavodsk: Kareliia, 1973.

Egorov, Andrei N. "Kadetskie organizatsii Vologodskoi gubernii v 1917-1918 gg.," Evropeiskii Sever: istoriia i sovremennost', 41-44. Petrozavodsk: KNTs AN SSSR, 1990.

Spirin, Leonid M. Klassy i partii v grazhdanskoi voine v Rossii. Moscow: Mysl', 1968.

Rappoport, Iurii M. Osushchestvlenie ekonomicheskoi politiki Kommunisticheskoi partii v usloviiakh Evropeiskogo Severa, 1917-1925. Leningrad: LGU, 1964.

Rothshtein, Andrew. When Britain Invaded Soviet Russia: The Consul Who Rebelled. London: Journeyman Press, 1979.

Army. The Evacuation of North Russia. 1919. London H.M. Stationary Office, 1920. 